\title{
The East Texas Bedding Plant Pack and Garden Performance Trials
}

\author{
H. Brent Pemberton ${ }^{1}$ and William E. Roberson ${ }^{2}$
}

AdDitional INDEX words. variety evaluation, field performance, Master Gardeners, bedding plant industry

Summary. The East Texas Bedding Plant Pack and Garden Performance Trials began several years ago at the Texas A\&M University Agricultural Research and Extension Center at Overton (Overton Center) with the goal of providing information on greenhouse and field performance of bedding plant varieties to the local bedding plant industry and consumers of these products. The program began with local trials that have now expanded in scope with the Smith County Master Gardeners Association playing an integral role in performing the trials. Entries are received from most of the major ornamental seed companies doing business in the United States giving the regional industry access to the only comprehensive greenhouse performance trials in this part of the country. Performance evaluation data is important to this industry since it has a wholesale value of over $\$ 500$ million in the northeast Texas region, of which over $\$ 100$ million is bedding plant production. The field performance trials are now replicated at the Overton Center, the Dallas Arboretum and Botanical Garden (Dallas Arboretum) and the Texas A\&M University Agricultural Research and Extension Center at Dallas (Dallas Center), giving over 5 million consumers in the northeast Texas region the opportunity to see how promising new plants from all over the world perform in the local climate. Plants that grow well in this climate have the potential to reduce inputs needed for production and use in the home or commercial landscape. Many of the top performing varieties from the bedding plant trials are also chosen to be part of the Coordinated Education and Marketing Assistance Program (CEMAP), a statewide testing program headquartered at the Dallas Center in which entries vie for designation as Texas Superstar ${ }^{\mathrm{TM}}$ plants. The comprehensive benefit of the East Texas Bedding Plant Pack and Garden Performance Trials is the link between the rural bedding plant producers and the urban consumers which serves as a basis for improving the quality of life for the citizens of Texas.

he East Texas Bedding Plant Pack and Garden Performance Trials
(Bedding Plant Performance Trials) began several years ago at the
Texas A\&M University Agricultural Research and Extension
Center at Overton, Texas with the goal of generating and providing information on greenhouse and field performance of bedding plant varieties to the local bedding plant industry and consumers of these products. The bedding plant production industry in northeast Texas is concentrated in Cherokee County and has an annual wholesale value of over $\$ 100$ million. This is a significant part of the $\$ 500$ million value of the ornamental industry in this region of the state and of the $\$ 1$ billion value for the entire state.

\footnotetext{
Texas A\&M University Agricultural Research and Extension Center, P.O. Box 200, Overton, Texas 75684-0200.

This manuscript includes programs supported and conducted by the Texas Agricultural Experiment Station, the Texas A\&M University System. Mention of a trademark, proprietary product, or vendor does not constitute a guarantee or warranty of the product by the authors, the Texas A\&M University System or the Texas Agricultural Experiment Station, and does not imply its approval to the exclusion of other products or vendors that also may be suitable. The cost of publishing this paper was defrayed in part by the payment of page charges. Under postal regulations, this paper therefore must be hereby marked advertisement solely to indicate this fact.

${ }^{1}$ Professor.

${ }^{2}$ Research assistant.
} 


\section{Scope of the trials}

Trials are performed in the spring and fall each year primarily for seed grown crops. Limited trials of vegetatively propagated material were started in Spring 2000 and will likely be expanded in the future. Invitations for participation in the trials are sent out late in the year for the upcoming trial year. Entries for both spring and fall are solicited at that time, and are accepted from most of the seed companies doing business in the U.S. A fee is paid per entry, which provides a significant source of financial support for the trial evaluation work. In addition, the local industry has been very supportive with donations of materials such as containers, growing media, and fertilizer needed to perform the trials. An average of 200 to 400 entries are received each trial season with more entries usually received for the spring than in the fall trials.

Speciescommonly grown for spring evaluation include wax begonia (Begonia $\times$ semperflorens-cultorum), petunia (Petunia $\times$ hybrida), bedding impatiens (Impatiens wallerana), vinca (Catharanthus roseus), penta (Penta lanceolata), verbena(Verbena $\times$ bybrida), nicotiana (Nicotiana alata), marigold (Tagetes sp.), melampodium (Melampodium paludosum), ornamental pepper (Capsicum species), geranium (Pelargonium $\times$ hortorum), lisianthus (Eustomagrandiflorum), and other species of interest to the industry. Sowing usually begins in early February and continues into March as needed. Cool season crops, such as petunia, are sown first while heat loving species, such as vinca, are sown last. For each crop, two flats are grown, one for the greenhouse pack evaluation and one for garden performance evaluation. The date that material is planted for the garden performance evaluation closely corresponds to the greenhouse flowering date for each entry in the greenhouse evaluation. However, the material for the greenhouse evaluation is usually held until all of the entries of a particular species have flowered so that some are overgrown by the end of the evaluation period. Growing material separately for the greenhouse and garden evaluations allows field planting to be done while plants are in prime condition. Early sown species such as petunia are usually flowering in the greenhouse evaluations by mid-April. The average date for the last frost at Overton is 15 Mar. Midseason crops such as wax begonia and bedding impatiens flower by early May. And, the late season crops such as vinca flower by late May. The field trials usually peak by late June. By early June, minimum night temperatures rise above $21^{\circ} \mathrm{C}\left(70^{\circ} \mathrm{F}\right)$ and approach $26.7^{\circ} \mathrm{C}\left(80^{\circ} \mathrm{F}\right)$ for most of July and August. Maximum day temperatures are above $32.2^{\circ} \mathrm{C}\left(90^{\circ} \mathrm{F}\right)$ by late June and approach $37.8^{\circ} \mathrm{C}\left(100^{\circ} \mathrm{F}\right)$ for most of July and August during which many entries decline.

Species commonly grown for fall evaluations include pansy (Viola $\times$ wittrockiana), dianthus (Dianthus chinensis), snapdragon (Antirrbinum majus), linaria (Linariamaroccana), sweet alyssum (Lobularia maritima), flowering cabbage and kale (Brassica oleracea), osteospermum (Osteospermum ecklonis), and other species of interest. Sowing usually begins in mid-August and continues into September if needed. All fall entries are sown as closely together as possible. Two flats of each entry are grown as in the spring. Entries are usually flowering in the greenhouse trials by late October to early November. Also at this time, the plants grown for the garden evaluation are planted. The first average frost date is $15 \mathrm{Nov}$. The field trials usually peak in February or early March and are in decline by late April. Overton is located near the line dividing USDA hardiness zones $7 \mathrm{~b}$ and $8 \mathrm{a}$ with typical seasonal lows between -9.4 and $-3.9^{\circ} \mathrm{C}(15$ and 25 $\left.{ }^{\circ} \mathrm{F}\right)$. Rarely, temperatures between -17.8 and $-12.2^{\circ} \mathrm{C}\left(0\right.$ and $\left.10^{\circ} \mathrm{F}\right)$ can be experienced, butseasonal lows are usually as brief as a few hours each night for just a few days. Rapid changes in temperature are not uncommon, but temperatures below freezing for more than $24 \mathrm{~h}$ are rarely experienced. Ice is more common than snow as unusual winter precipitation events.

\section{How the trials are performed}

Greenhouse trials. Seed are typically sown in plug trays with 288 cells [9.2 $\mathrm{cm}^{3}\left(0.6\right.$ inch $\left.^{3}\right)$ per cell] (Dillon Products, Middlefield, Ohio) using LG3 germination media (SunGro Horticulture, Bellevue, Wash.). Seed are covered lightly with the same media if needed. Uncovered seed are covered with plastic wrap for germination. For the spring trials, germination is usually in a glasshouse as needed conditions can be easily maintained at the time of year sowing is accomplished. For the fall trials, all entries are germinated in controlled environment rooms due to summer heat. Light is provided if needed during germination and emerging seed-

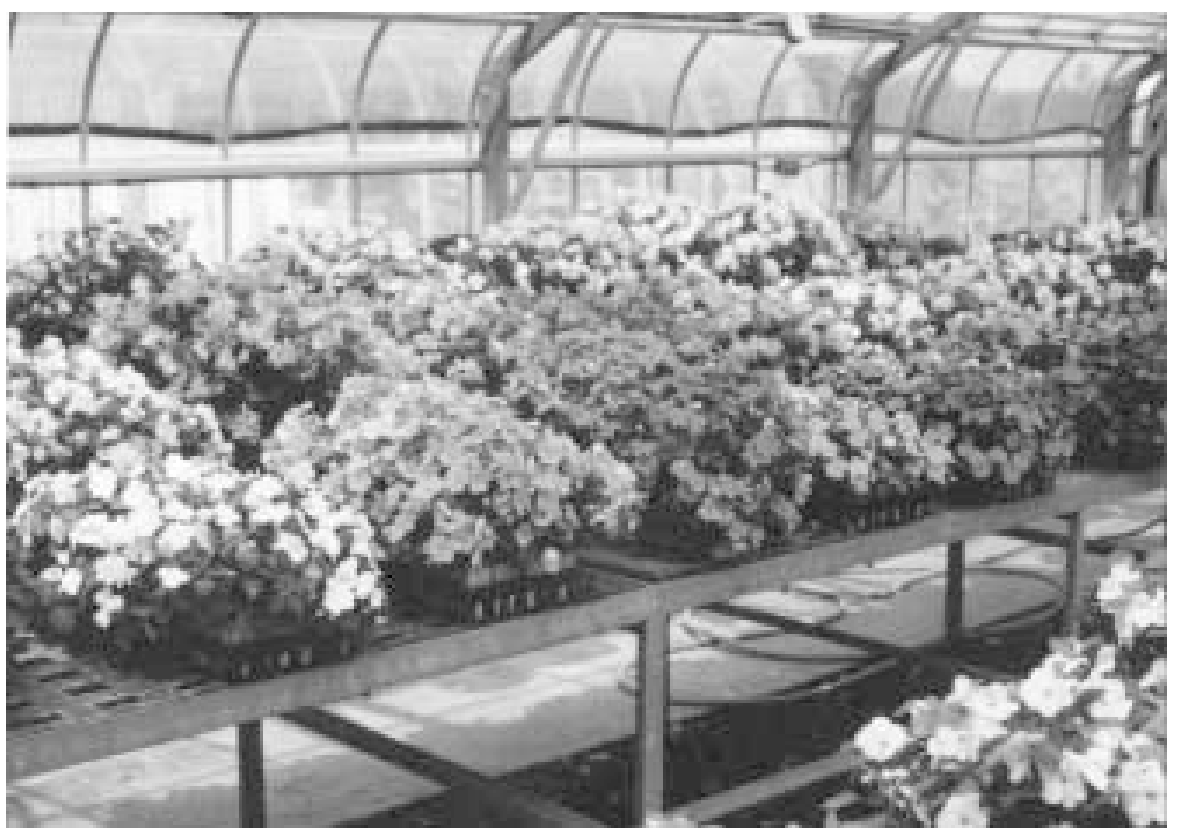

Fig. 1. View of a spring greenhouse bedding impatiens (Impatiens wallevana) trial which is a part of the East Texas Bedding Plant Pack and Garden Performance Trials. Each flat is evaluated separately. Note the differences in height between the entries. Growth regulators are used at moderate rates for the trials in order to not mask the height differences inherent between the entries. These trials are performed at the Texas A\&M University Agricultural Research and Extension Center at Overton. 


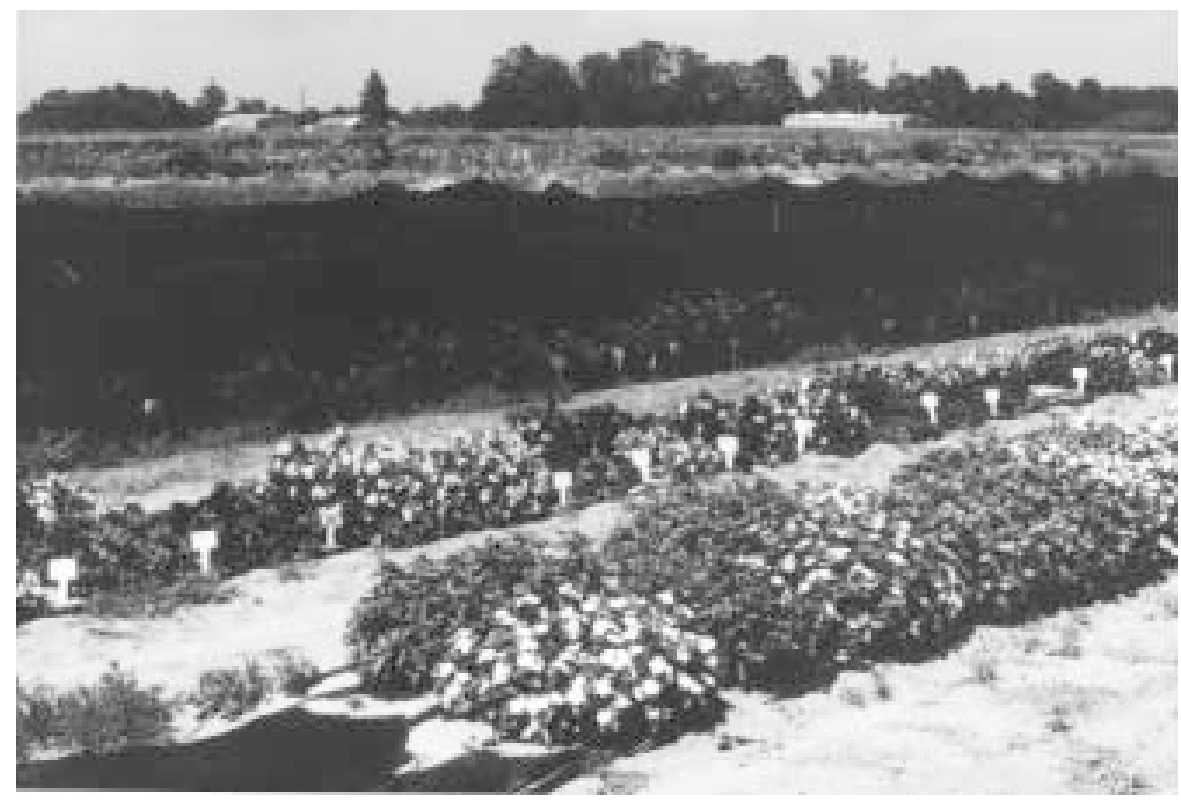

Fig. 2. View of spring field trials that are part of the East Texas Bedding Plant Pack and Garden Performance Trials. Note the center structure that is used for shade trials. For shade trials, boxes that are $90 \mathrm{~cm}(3 \mathrm{ft})$ high and wide are constructed over the beds running lengthwise using $t$-posts and wire from which 30\% saran shade is draped to cover the tops and sides These trials are performed at the Texas A\&M University Agricultural Research and Extension Center at Overton.

lings are moved to a glasshouse as soon as possible after radicle emergence to prevent stretching of the hypocotyl.

After establishment under glasshouse conditions, the plugs are transplanted into one flat per entry using jumbo 906 packs and LC-1 media (SunGroHorticulture, Bellevue, Wash.). Jumbo 906 packs $\left[185 \mathrm{~cm}^{3}\left(11.3\right.\right.$ inch $\left.^{3}\right)$ per cell with six cells per pack and nine packs per flat) (Landmark Plastics, Akron Ohio) are becoming common in the local industry, though 606 packs are also still used (see below). Fertilization starts at germination using $0.67 \mathrm{oz} /$ $100 \mathrm{gal}\left[50 \mathrm{mg} \cdot \mathrm{L}^{-1}(\mathrm{ppm})\right]$ of nitrogen (N) from 15-5-15 (15N-1.5P-12.5K) Excel Cal-Mag (Scotts-Sierra Horticultural Products Company, Marysville, Ohio). After the second set of true leaves form, the rate is increased to 1.3 $\mathrm{Oz} / 100 \mathrm{gal}\left(100 \mathrm{mg} \cdot \mathrm{L}^{-1}\right)$ of $\mathrm{N}$. The rate is increased to 2 to $2.7 \mathrm{oz} / 100 \mathrm{gal}$ ( 150 to $\left.200 \mathrm{mg} \cdot \mathrm{L}^{-1}\right)$ of $\mathrm{N}$ after transplanting depending on the species. Fertilization is supplemented weekly with $0.07 \mathrm{oz} /$ $100 \mathrm{gal}\left(5 \mathrm{mg} \cdot \mathrm{L}^{-1}\right)$ of iron using the DTPA chelate (Miller Chemical and Fertilizer Corporation, Hanover, Pa.).

Growth regulators are used to control the height of both plugs and transplants with the specific chemical and rate being dictated by the species and would be desired in a commercial situation. In this way, differences can be discerned between entries that are meaningful to producers and information can be gained on the level of growth regulator use that will be required by a particular entry when grown under local conditions.

As entries begin to flower, data are collected based on the performance of the individual flats grown for the greenhouse evaluation(Fig. 1). Measurements include days to first flower, days to $50 \%$ flowering (when about $50 \%$ of the plants in the flat are in flower), and height at $50 \%$ flowering (plant height including flowers in the center of the flat). Also at $50 \%$ flowering, a performance rating is assigned based on a scale of 1 (worst) to 10 (best) using parameters including flowering, height, and uniformity of growth and flowering within the flat. For example, 5 = uneven growth, several flowers, moderate form and habit; 8 = uniform growth, moderate height, many flowers, superior form and habit; $10=$ uniform growth, compact height, uniform full flowering, superior form and habit. Additional data may be recorded if needed for a particular species (e.g., flower size, peduncle height) or desired by a sponsor.

Field trials. Entries are grown from seed as described for the greenhouse trials. They are then field planted from jumbo packs following acclima-

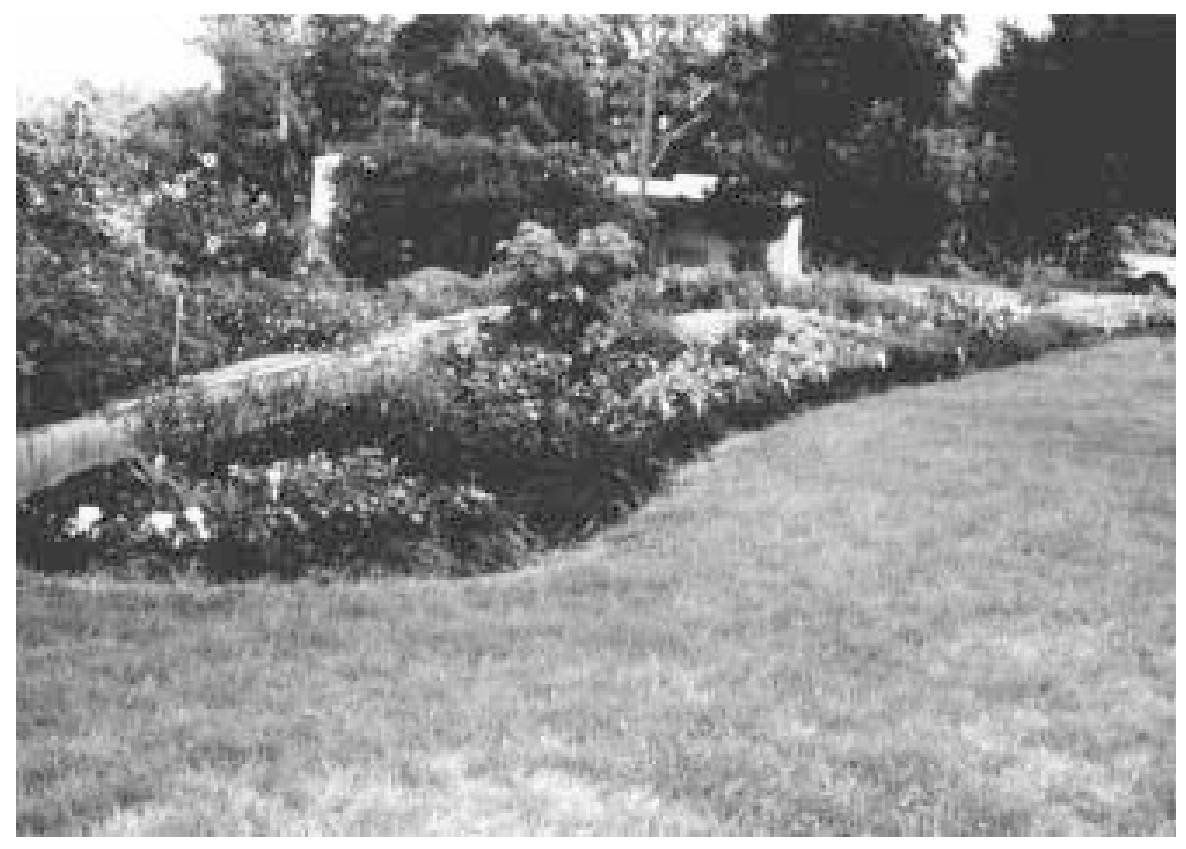

Fig. 3. The Overton Center Research and Demonstration Garden at the Texas A\&M University Agricultural Research and Extension Center at Overton. The paths used to be walkways in an old greenhouse that was demolished. 


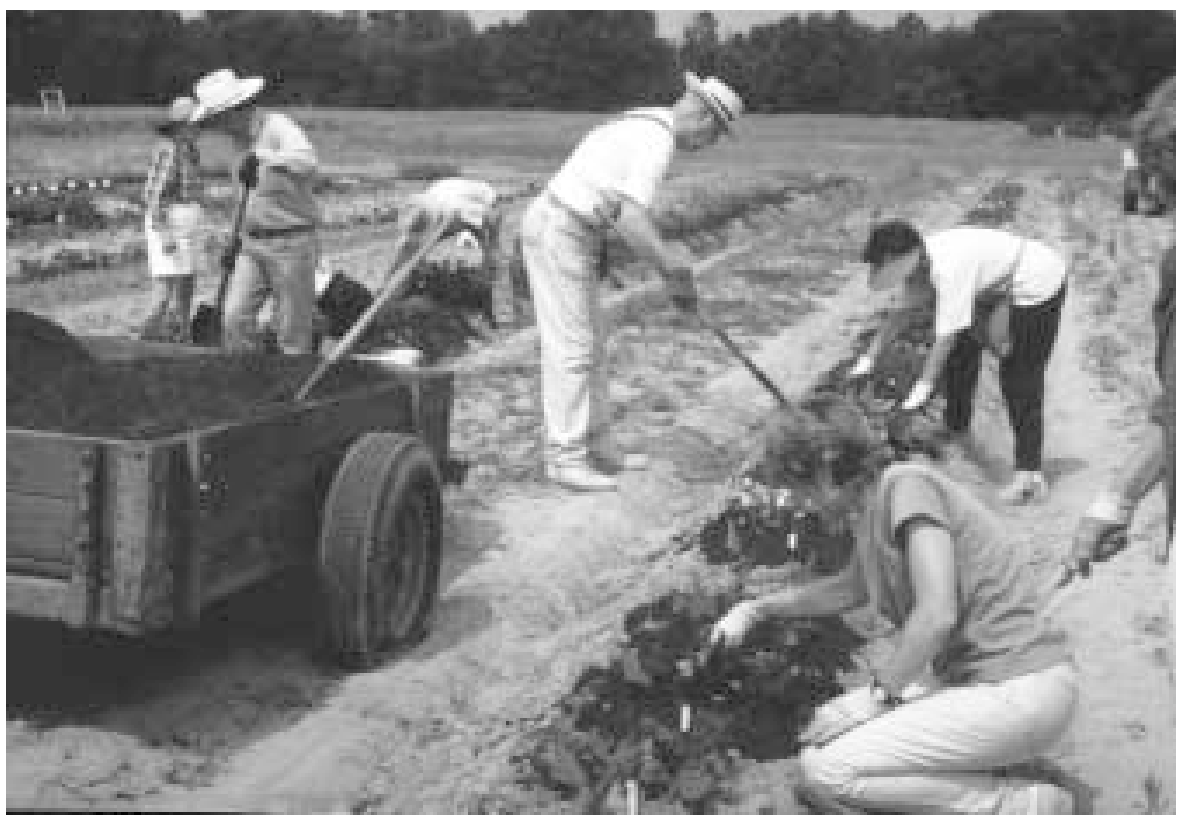

Fig. 4. Master Gardeners from the Smith County Master Gardener's Association planting field trials that are part of the East Texas Bedding Plant Pack and Garden Performance Trials at the Texas A\&M University Agricultural Research and Extension Center at Overton.

tion outdoors before planting (Fig. 2). Plants are usually just starting to flower when field planted. Jumbo 606 packs $\left[206 \mathrm{~cm}^{3}\left(12.6\right.\right.$ inch $\left.^{3}\right)$ per cell with six cells per pack and six packs per flat] (Landmark Plastics, Akron, Ohio) are used as these are still used by some in the local industry. Since one flat per entry is planted for the field trials, a flat of 606 packs provides enough plants for field planting whereas a flat of 906 packs would require more plants than are needed. The field soil is a Bowie fine sandy loam with a usually acidic $\mathrm{pH}$ adjusted to about 6 or 6.5 with additions of dolomitic lime. Trials are rotated with grass crops such as rye to build up organic matter between cropping cycles. Planting beds $91.4 \mathrm{~cm}(36$ inches $)$ wide and $2.4 \mathrm{~m}(8 \mathrm{ft})$ apart are constructed in rows that are covered with 1.25 -mil [0.032-mm $(0.00125$ inch)] embossed black plastic mulch (Huntsman Corporation, Herrington, Del.). T-Tape TSX (T-Systems, San Diego, Calif.) is run down the middle of the beds under the plastic for drip irrigation. Holes are punched with bulb planters for planting using spacings appropriate for the species ranging from $15-\mathrm{cm}(6-\mathrm{inch})$ centers for pansy and wax begonia to $30-\mathrm{cm}(1-\mathrm{ft})$ centers for ground cover petunias. For shade trials, boxes that are $90 \mathrm{~cm}(3 \mathrm{ft})$ high and wide are constructed over the beds running lengthwise using t-posts and wire from which $30 \%$ saran shade is draped to cover the tops and sides (Fig. 2).

Plants are irrigated as needed using drip irrigation. Rainfall averages $113 \mathrm{~cm}$ (45 inches) per year which is relatively well distributed, but most falls from fall through spring. Periods of 30 to $90 \mathrm{~d}$ with very little rainfall between late June and mid-September are not unusual. Humidities are usually moderate, but can be high during periods of heavy rain such as in May and June, low during periods of low rainfall during the summer, and high again when associated with cool weather in the fall, winter, and spring. Plants are fertilized through the drip system using a $20-20-20(20 \mathrm{~N}-6 \mathrm{P}-$ 16.6K) water soluble fertilizer (Carl Pool Products, Gladewater, Texas) at the rate of $16.8 \mathrm{~kg} \cdot \mathrm{ha}^{-1}(15 \mathrm{lb} /$ acre $)$ of $\mathrm{N}$ per week. Hand weeding is done in the beds and along the edges as needed, while the areas between the beds are cultivated for weed control. Removal of spent flowers is not generally practiced except for some species such as petunia which benefit from a periodic shearing during the growing season. Insects and diseases are closely monitored, but control is not generally practiced as plant responses to these challenges are part of the trial results. However, some preventative control is used. For example, bedding impatiens are sprayed preventively for thrips to prevent outbreaks of impatiens necrotic spot virus as no tolerance to this disease is known.

Entries are planted in plots of six or nine plants depending on the species. A randomized complete block design with three replications is used. If there are only a few entries of a species, 12 to 18 plants are planted in nonreplicated plots for evaluation. For species such as wax begonia, both shade and sun trials are performed due to the importance of this species for both exposures in our region. As entries begin to flower, ratings are made. Every 2 weeks, a flowering rating is made using a scale of 1 to 10 which is based on percent flowering (for example, $1=$ $0 \% ; 2=1 \%$ to $25 \%$; and $5=76 \%$ to $100 \%$ flowering). Every 4 to 5 weeks, a performance rating is assigned using a scale of 1 to 10 that is based upon flowering, habit, health of the foliage, and uniformity of growth and flowering within a plot. For example, $5=$ uniform, healthy plants, but with somewhat weak or floppy growth, flowering about $25 \%$, or good flowering with a floppy growth habit; $8=$ very uniform, healthy plants with vigorous growth and flowering at least $75 \%$, but not heavy; and $10=$ highly uniform, healthy plants with very vigorous growth and very heavy flowering. Plant height is measured when each species is at peak performance. Other parameters such as flower size are measured if of interest for a species or desired by the sponsor.

\section{The Overton Center Research and Demonstration Garden}

In addition to the greenhouse and field trials, a research and demonstration garden has been established at the Overton Center for several purposes (Fig. 3). The site at the main complex of the Overton Center was once a research greenhouse that was demolished when new ones were built many years ago. The site was well suited for garden use as beds could be built where there once were benches and the concrete walkways were already in place for convenient access. The area is also adjacent to established parking areas for the main building at the Overton Center. This garden has proven to be an excellent venue for the testing of perennial crops, which is not possible in the field trials as 
the trial area must be rotated for annual trials. It has also proven to be valuable for testing perennials with unknown hardiness and as a showcase for disease resistant roses as determined in another field testing program performed at the Overton Center. Another valuable role has been as a testing and showcase site for the Texas Superstar' program which is described in this issue (Mackay et al., 2001). An expansion of the garden was accomplished in Spring 2000 in cooperation with the Mast Arboretum at Stephen F. Austin State University, Nacogdoches, Texas.

\section{Outreach and important linkages}

Two of the primary outreach programs for the Bedding Plant Trials are open houses and field days. Open houses featuring the greenhouse trials are held in May and October for the spring and fall trials, respectively. These are generally of more interest to bedding plant producers and ornamental seed company representatives than to the general public. Field days are held in June and February each year and have proven popular with Master Gardeners and the general public. In addition to these programs, presentations are made at regional and national industry events as well as consumer oriented conferences. Reports are also prepared, but circulation is limited by logistics and expense. A web site is now under construction at <http://overton.tamu.edu/flowers/> (Pemberton and Pemberton, 2000) so that data from the trials can be presented with links to images of the individual entries.

One of the most rewarding aspects of the Bedding Plant Trials has been the opportunities that have arisen for forging linkages among various groups. $\mathrm{Al}$ ready mentioned are the ornamental seed companies, the regional bedding plant industry, the Texas Superstar ${ }^{\mathrm{TM}}$ program, and the Mast Arboretum. Another integral part of the trial program is the Smith County Master Gardener
Program. Master Gardeners provide hundreds of volunteer hours each trial season for planting seed, transplanting plugs, field planting, and trial garden maintenance (Fig. 4). In return, they receive credit for required volunteer hours and continuing education credits. The Overton Center has also become a popular site for Master Gardener training sessions and tours. Without the support of the Master Gardeners, the bedding plant trials would not be possible.

Recently, the trials have been expanded to sites at the Dallas Arboretum and the Dallas Center. Plants are produced at the Overton Center and transported to these sites for trial. The heavy, alkaline soils of these sites are in stark contrast to the acid, sandy soils at the Overton Center. At the Dallas Center, entries that look promising in the more comprehensive trials at Overton and the Dallas Arboretum are trialed as a first step in entering them into the statewide Texas Superstar ${ }^{\text {тм }}$ testing program (Mackay et al., 2001). At the Dallas Arboretum, all entries in the spring and fall trials are replicated in a setting that is viewed by over 300,000 visitors each year. The trials at the Dallas sites facilitate a critical linkage between the rural bedding plant production industry and the urban consumers that represent a major market for their product. In this way, the quality of life of the citizens of Texas can be improved by enabling the industry to offer consumers plants with proven performance.

\section{Literature cited}

Mackay, W.A., S.W. George, T.D. Davis, M.A. Arnold, R.D. Lineberger, J.M. Parsons, L.A. Stein, and G.D. Grant. 2001. Texas Superstar and the Coordinated Educational and Marketing Assistance Program (CEMAP), how we operate. HortTechnology 11(3):389-391.

Pemberton, H.B. and I.J. Pemberton. 2000. East Texas bedding plant pack and garden trials. 10 Apr. 2001. <http:// overton.tamu.edu/flowers $/>$. 